\title{
Cadmium accumulation and its effects on physiological characteristics of Arundo donax L. in a simulated wetland
}

\author{
Pu G. ${ }^{1 *}$, Zeng D. ${ }^{1}$, Mo L. ${ }^{1}$, Liao J. ${ }^{1}$, Xu G. ${ }^{1}$, Huang Y. ${ }^{2}$ and Zhang C. ${ }^{3}$ \\ ${ }^{1}$ Guangxi Key Laboratory of Plant Conservation and Restoration Ecology in Karst Terrain, Guangxi Institue of Botany, Guangxi Zhuang \\ Autonomous Region and Chinese Academy of Sciences, 85 Yanshan Street, Yanshan District, Guilin, 541006, P.R. China \\ ${ }^{2}$ Key Laboratory of Environment Change and Resources Use in Beibu Gulf, Guangxi Teachers Education University, Nanning, 530001, \\ P.R. China \\ ${ }^{3}$ School of Resources, Environment and Materals, Guangxi University, Nanning, 530004, P.R. China \\ Received: 11/01/2018, Accepted: 04/09/2018, Available online: 26/09/2018 \\ *to whom all correspondence should be addressed: e-mail: pukouchy@hotmail.com \\ https://doi.org/10.30955/gnj.002580
}

\section{Abstract}

A simulated wetland experiment was used to investigate the effect of cadmium (Cd) on the growth of Arundo donax, as well as its photosynthetic characteristics and antioxidant enzyme activities. Cd accumulation in the order of stem < roots < leaves increased gradually with increasing $\mathrm{Cd}$ concentrations. Due to the higher transport of $\mathrm{Cd}$, its accumulation in the aboveground parts of A. donax was nearly 2 times that in belowground parts. There were no differences in physiological parameters, such as the relative chlorophyll content (SPAD), the potential $\left(F_{v} / F_{m}\right)$ or effective $(Y)$ photochemical efficiency of PSII, and photosynthetic rate (Pn). There were slight changes in transpiration rate $(\mathrm{Tr})$, intercellular $\mathrm{CO}_{2}$ concentration (Ci) and stomatal conductivity (Gs). The activity of superoxide dismutase (SOD) was stimulated by $\mathrm{Cd}$ treatments, and the decrease in catalase (CAT) was compensated by the induction of peroxidase (POD) suggesting these two enzymes function concurrently to remove $\mathrm{H}_{2} \mathrm{O}_{2}$. These results indicate that despite the oxidative stress involved in the mechanism of $\mathrm{Cd}$ toxicity associated with the high transport of $\mathrm{Cd}$ in $A$. donax, its photosynthetic system was not harmed. This suggests a strong tolerance of this species to increased $\mathrm{Cd}$ pollution and its potential use for phytoremediation purposes in wetland environment.

Keywords: Arundo donax, antioxidant enzymes, chlorophyll fluorescence, gas exchange parameters.

\section{Introduction}

Cadmium ( $\mathrm{Cd}$ ) is a typical, heavy metal pollutant with high toxicity and high solubility in water, soil and sediments; hence, it poses a serious environmental concern (Pinto et al., 2004; He et al., 2017). Cadmium, at trace levels, can undermine ecosystem functioning and human health (Zhi et al., 2016). Therefore, how to effectively control cadmium pollution and restore the ecological environment is one of the most urgent environmental problems. Although the toxicity effects of $\mathrm{Cd}^{2+}$ in plants have been well studied, some questions still remain unaddressed (He et al., 2017).

In general, excess $\mathrm{Cd}$ accumulation in plants can profoundly interfere with a series of physiological processes such as uptake, transport, and assimilation of mineral nutrients and photosynthesis, and thereby lead to nutrient deficiency, disruption of ATPase activity, decrease of photosynthesis, inhibition of various enzyme activities, induction of oxidative stress and reduce genotoxicity (Metwally et al., 2005; Imran et al., 2008; Johna et al., 2009; Chen et al., 2012; Alshaal et al., 2015; Çikili et al., 2016; Moussa et al., 2016; Shahid et al., 2017; He et al., 2017). These studies also suggested that the accumulation of and tolerance to $\mathrm{Cd}$ in plants varied greatly among plant species (Çikili et al., 2016), cultivars (Chen et al., 2012) and genotypes (Imran et al., 2008). For example, Metwally et al. (2005) reported that, in the selected ten genotypes of Pisum sativum L., Cd toxicity expression has both similarities and distinct features. In addition, some important environment factors (such as soil $\mathrm{PH}$, organic matter and microorganisms) have governed the sorption/desorption processes and chemical speciation of $\mathrm{Cd}$ in soils (Sappin-Didier et al., 2005; Liu et al., 2017). Obviously, plant species in different environments would show a wide range of plasticity in $\mathrm{Cd}$ tolerance. Therefore, it is important to understand the response of plants to $\mathrm{Cd}$ in different environments, and then carry out phytoremediation.

Phytoremediation is a growing field of research in environmental studies due to the advantages of its environmental friendliness, safety, and cost-effectiveness (Malik, 2007; Mirza et al., 2010; Elhawat et al., 2014). Although hyperaccumulation as a tool for cleaning up metal contaminated environments has been widely suggested (Leitenmaier and Küpper, 2013), the process is often linked with slow growth rate and low biomass production. As a result, net removal of metals via phytoextraction is quite limited (Elhawat et al., 2014). Therefore, the use of low-cost, fast-growing indigenous 
plants with efficient biomass production, such as giant reed (Arundo donax L.), is highly desirable for phytoremediation of metal contaminated sites and waters. A. donax is a perennial rhizomatous grass (Poaceae family) native to the freshwater regions of Eastern Asia. Because of its large biomass, high adaptability and unique physiological features, it readily absorbs and concentrates toxic chemicals from contaminated soil (Elhawat et al., 2014). Furthermore, A. donax has gained a broad reputation as a good candidate for use in energy production, the paper industry, biofuels and the development of building materials (Nassi et al., 2010; Elhawat et al., 2014). As a C3-grass, A. donax shows high photosynthetic rates and unsaturated photosynthetic potential compared to $\mathrm{C}_{4}$ plants (Alshaal et al., 2015). Previous studies have shown that, under high levels of cadmium, arsenic, plumbum, chromium and nickel stress, $A$. donax can growth and remain healthy, with its photosynthetic system unharmed (Alshaal et al., 2015). This ability is based on its high antioxidant capacity, which allows its antioxidative enzymes to catalyse the dismutation of highly reactive $\mathrm{O}_{2}^{-}$into non-toxic forms, such as $\mathrm{O}_{2}$ and $\mathrm{H}_{2} \mathrm{O}$ (Miao et al., 2012). These results indicate that metals, such $\mathrm{Cd}, \mathrm{Ni}, \mathrm{As}, \mathrm{Cr}$ and $\mathrm{Pb}$, are most likely sequestered in a very effective manner within the A. donax plant, thus providing potent protection of the photosynthetic machine. There are several works concerning the promising phytoremediation potential of A. donax as applied to bauxite residue/red mud (Alshaal et al., 2013), urban wastewater and saline lands (Williams et al., 2008; Mirza et al., 2010; Zema et al., 2012; Elhawat et al., 2014), marginal lands (Nassi et al.,
2013) and metals polluted soil (Papazoglou et al., 2005; Miao et al., 2012; Shabana et al., 2012; El-Ramady et al., 2014; Liu et al., 2017). However, there is limited data on the physiological responses of $A$. donax to $C d$ stress in wetland environment and the capacity of A. donax to aid in the recovery of Cd-contaminated wetlands.

Thus, our objective was to monitor the uptake and translocation of $\mathrm{Cd}$ in $A$. donax and to investigate plant growth responses, photosynthetic characteristics and antioxidant enzyme activities of $A$. donax under different levels of $\mathrm{Cd}$ stress.

\section{Material and methods}

\subsection{Test soil and plant}

A mixed medium of soil and water, collected from the garden of the Guangxi Institute of Botany, was used to simulate the wetland environment. The basic physiochemical properties of soil and water were analyzed (Table 1$)$. The test soil ( $5 \mathrm{~kg}$ ) was placed in plastic pots (base diameter $\times$ height $\times$ outside diameter: $26 \mathrm{~cm} \times 75 \mathrm{~cm} \times 38.5 \mathrm{~cm}$ ) and the volume of the water was always maintained at $4 \mathrm{~L}$ above that of the soil $(3.9 \pm 0.3 \mathrm{~cm})$. Test soil in each pot was homogeneously sprayed with aqueous solutions containing $0.00,0.01$, $0.025,0.05,0.125$ and $2.5 \mathrm{mg} \mathrm{Cd}$ per liter of water that were prepared by dissolving salts of $\mathrm{CdCl}_{2} \cdot 2.5 \mathrm{H}_{2} \mathrm{O}$. The soil-grown plants were obtained from young meristematic buds in tissue culture grown in sterile aqueous medium.

Table 1. Basic physiochemical properties of tested soil and water

\begin{tabular}{cccccccc}
\hline \multirow{2}{*}{ Soil } & $\mathrm{pH}$ & $\mathrm{TN}\left(\mathrm{g} \mathrm{kg}^{-1}\right)$ & $\mathrm{TP}\left(\mathrm{g} \mathrm{kg}^{-1}\right)$ & $\mathrm{TK}\left(\mathrm{g} \mathrm{kg}^{-1}\right)$ & $\mathrm{AN}\left(\mathrm{mg} \mathrm{kg}^{-1}\right)$ & $\mathrm{AP}\left(\mathrm{mg} \mathrm{kg}^{-1}\right)$ & $\mathrm{Cd}\left(\mathrm{mg} \mathrm{kg}^{-1}\right)$ \\
\cline { 2 - 8 } & 6.50 & 1.167 & 0.80 & 0.78 & 181.26 & 3.72 & 0.01 \\
\hline \multirow{2}{*}{ Water } & $\mathrm{pH}$ & $\mathrm{DO}\left(\mathrm{mg} \mathrm{L}^{-1}\right)$ & $\mathrm{SpC}\left(\mu \mathrm{s} \mathrm{cm}^{-1}\right)$ & $\mathrm{Ca}^{2+}\left(\mathrm{mg} \mathrm{L}^{-1}\right)$ & $\mathrm{Mg}^{2+}\left(\mathrm{mg} \mathrm{L}^{-1}\right)$ & $\mathrm{HCO}_{3}^{-}\left(\mathrm{mmol} \mathrm{L}^{-1}\right)$ & $\mathrm{Cd}^{\left(\mu \mathrm{g} \mathrm{L}^{-1}\right)}$ \\
\cline { 2 - 9 } & 7.38 & 1.56 & 235.00 & 53.00 & 7.63 & 1.70 & $<0.001$ \\
\hline
\end{tabular}

Note: TN, total nitrogen; TP, total phosphorus; TK, total potassium; $A N$, ammonia nitrogen; $A P$, available phosphorus; $D O$, dissolved oxygen; $S p C$, specific conductance

\subsection{Culture and harvest of plant}

A. donax was cultivated in a greenhouse with day/night temperatures of $28 / 20{ }^{\circ} \mathrm{C}$ and a relative humidity of $65 \%$. During the growing period of $A$. donax, the volume of the water was always maintained at $4 \mathrm{~L}$ above that of the soil $(3.9 \pm 0.3 \mathrm{~cm})$. After four months of cultivation, photochemical efficiency, photosynthetic gas exchange parameters and antioxidant enzymes activities were determined for each of the plants. Then, the plants were harvested and carefully washed with tap water and deionized water. Parts of fresh leaves were selected for the determination of enzyme activities. The remaining samples including leaves, stems and roots were then separated, cut with stainless steel scissor, and dried at 40 ${ }^{\circ} \mathrm{C}$ for $72 \mathrm{~h}$ for elemental analysis. $\mathrm{Cd}$ was determined in the soil and plants using the methods of Sasmaz et al. (2016) and Mazur et al. (2016) respectively. Soil samples were digested in a mixture of $\mathrm{HNO}_{3}: \mathrm{HCl}: \mathrm{H}_{2} \mathrm{O}$
( $6 \mathrm{ml}$ per $1.0 \mathrm{~g}$ of soil, v/v: 1:1:1) for 1 hour at $95{ }^{\circ} \mathrm{C}$. The plant samples were digested in nitric acid by microwave reaction system (Multiwave PRO, Austria) and the temperature control settings were as follows: $5 \mathrm{~min}$, $95{ }^{\circ} \mathrm{C}$; $10 \mathrm{~min}, 180{ }^{\circ} \mathrm{C}$; $45 \mathrm{~min}, 200{ }^{\circ} \mathrm{C}$. $(200 \mathrm{mg}$ in $3 \mathrm{~mL}$ conc. $\mathrm{HNO}_{3}$ ). Following digestion all the samples were determined by inductively coupled plasma-mass spectrometry (ICP-MS, PerkinElmer Instruments, USA). The phytoextraction ability of $A$. donax L. plants was assessed using a translocation factor (TF) and a bioaccumulation factor (BF) as follows:

$$
\begin{aligned}
& \mathrm{TF}=[\mathrm{Cd}]_{\text {shoot }} /[\mathrm{Cd}]_{\text {root }} \\
& \mathrm{BF}=[\mathrm{Cd}]_{\text {shoot }} /[\mathrm{Cd}]_{\text {soil }}
\end{aligned}
$$

\subsection{Photosynthetic parameters}

Chlorophyll fluorescence parameters and photosynthetic gas exchange parameters were determined by the method described by Lichtenthaler et al. (2005) using LI-6400XT (Li-Cor, Linconn, USA) and portable fluorometer 
(Monitoring-PAM, Walz, Germany). Photosynthetic rate $(\mathrm{Pn})$, transpiration rate $(\mathrm{Tr})$, intercellular $\mathrm{CO}_{2}$ concentration ( $\mathrm{Ci}$ ) and stomatal conductivity (Gs) were measured from the middle region of the topmost fully expanded leaf at $25{ }^{\circ} \mathrm{C}$ under a light intensity of $1,200 \mu \mathrm{mol} \mathrm{m} \mathrm{m}^{-2} \mathrm{~s}^{-1}$, relative humidity of $40 \%$, and $\mathrm{CO}_{2}$ concentration of $370 \mu \mathrm{mol} \mathrm{mol} \mathrm{m}^{-1}$. The top-most fully expanded leaves of treated and control plants were first light- and dark-adapted for 20 min to obtain the minimum $\left(F_{0}\right)$ and maximum $\left(F_{m}\right)$ chlorophyll fluorescence. The potential photochemical efficiency of PSII was calculated using the following formula:

$\mathrm{F}_{\mathrm{v}} / \mathrm{F}_{\mathrm{m}}=\left(\mathrm{F}_{\mathrm{m}}-\mathrm{F}_{0}\right) / \mathrm{F}_{\mathrm{m}}$

where $F_{v}$ is the variable fluorescence. The effective photochemical efficiency of PSII, $Y$, was determined according to Genty et al. (1989) using the following formula:

$\mathrm{Y}=\left(\mathrm{F}_{\mathrm{m}}-\mathrm{F}^{\prime}{ }_{0}\right) / \mathrm{F}_{\mathrm{m}}^{\prime}=\Delta \mathrm{F} / \mathrm{F}_{\mathrm{m}}^{\prime}$

where $F_{0}{ }^{\prime}$ is the minimum fluorescence after dark adaptation, $F_{m}^{\prime}$ is the maximum fluorescence after dark adaptation and $\Delta F$ is the fluorescence spike at the end of the induction kinetic on top of the AL-induced kinetics. The relative chlorophyll content was estimated using a SPAD-502 Plus meter (Konica Minolta, Osaka, Japan) and is given as SPAD values, which are proportional to the chlorophyll content in leaves. All measurements were taken from five plants in each treatment replicate between 08:00 to 11:00 a.m.

\subsection{Antioxidant enzymes activities}

The activities of superoxide dismutase (SOD), peroxidase (POD) and catalase (CAT) were assayed by following the protocols of Shah et al. (2012) with slight modification. Leaves $(0.3 \mathrm{~g})$ were homogenized in $5 \mathrm{~cm}^{3}$ of ice-cold $50 \mathrm{mM}$ phosphate buffer at a pH 6.5 (for POD, SOD) and a $\mathrm{pH} 7.5$ (CAT). The extracts were centrifuged at $10000 \mathrm{~g}$ for $20 \mathrm{~min}$ at 0 to $4{ }^{\circ} \mathrm{C}$ in a Beckmann refrigerated centrifuge, and the supernatants were used for the enzyme activity assays.

\subsection{Data analysis}

All data were statistically analyzed using SPSS (Version 18.0). Cd accumulation values are expressed as the means \pm standard deviation (SD) of the four replicates. An ANOVA was applied to examine statistical significant differences among the addition levels of soil amendments. A probability level of $P<0.05$ was considered significant, unless otherwise stated.

\section{Results and discussion}

\subsection{Effects of $C d$ on biomass and growth of $A$. donax}

During the vegetative stages of plant development, all treatments showed no detrimental or toxic effects (Table 2). The morphological characteristics, as well as the leaf and root biomasses of $A$. donax, did not show statistically significant differences compared with control (Table 2). However, the stem biomass showed statistically significant differences between the control and heavy-metal treated plants (Table 2). This indicated that the stems may be the Cd-sensitive organs in $A$. donax, which agrees with previous studies that showed that the reduction of shoot dry biomass caused by $\mathrm{Cd}$ application has been demonstrated in many species of plants (Çikili et al., 2016). On the basis of the reduction rate in the shoot dry biomass of plants, $A$. donax was determined to be Cd-tolerant according to the scale suggested by Shahbaz et al. (2011) as tolerant for the reduction rate of $<30 \%$. Previous studies also showed that $A$. donax is only slightly affected by the presence of metals such as cadmium, nickel, arsenic and lead in the rhizosphere on soil medium. This trait makes the plant suitable for contaminated soils and polluted areas, where it is capable of high biomass production (Papazoglou et al., 2005; Mirza et al., 2010; Kausar et al., 2012).

Table 2. The biomass of $A$. donax after four months of growth in a Cd-contaminated soil-water medium

\begin{tabular}{cccccc}
\hline \multirow{2}{*}{$\begin{array}{c}\text { Concentration } \\
\left(\mathbf{m g ~ L}^{-1}\right)\end{array}$} & $\begin{array}{c}\text { Height } \\
(\mathbf{c m})\end{array}$ & $\begin{array}{c}\text { Number } \\
\text { of } \\
\text { nodes }\end{array}$ & \multicolumn{2}{c}{ Biomass of $\boldsymbol{A}$. donax (g) } \\
\cline { 5 - 6 } & $56^{\mathrm{a}}$ & $11^{\mathrm{a}}$ & $10.0^{\mathrm{a}}$ & $18.4^{\mathrm{a}}$ & $14.8^{\mathrm{a}}$ \\
\hline 0.00 & $62^{\mathrm{a}}$ & $9^{\mathrm{a}}$ & $8.9^{\mathrm{a}}$ & $13.5^{\mathrm{b}}$ & $8.8^{\mathrm{a}}$ \\
\hline 0.01 & $52^{\mathrm{a}}$ & $13^{\mathrm{a}}$ & $12.8^{\mathrm{a}}$ & $13.8^{\mathrm{b}}$ & $10.3^{\mathrm{a}}$ \\
\hline 0.025 & $65^{\mathrm{a}}$ & $10^{\mathrm{a}}$ & $10.2^{\mathrm{a}}$ & $14.7^{\mathrm{b}}$ & $9.2^{\mathrm{a}}$ \\
\hline 0.05 & $66^{\mathrm{a}}$ & $9^{\mathrm{a}}$ & $10.2^{\mathrm{a}}$ & $14.0^{\mathrm{b}}$ & $11.3^{\mathrm{a}}$ \\
\hline 0.125 & $60^{\mathrm{a}}$ & $10^{\mathrm{a}}$ & $9.1^{\mathrm{a}}$ & $13.1^{\mathrm{b}}$ & $13.8^{\mathrm{a}}$ \\
\hline 2.50 & &
\end{tabular}

Note: Data represent average mean from four repetitions. Data with different superscript letters indicate a significant difference at $P<0.05$

\subsection{Accumulation of $C d$ in $A$. donax}

The accumulation of $\mathrm{Cd}$ in the plants (including roots, leaves and stems) and soil all showed a positive correlation with $\mathrm{Cd}$ concentration, and the order of $\mathrm{Cd}$ accumulation was stem < roots < leaves (Table 3 ). The maximum accumulation of $\mathrm{Cd}$ was found in plants at $2.50 \mathrm{mg} \mathrm{L}^{-1}$, at which the $\mathrm{Cd}$ concentrations in leaves, roots and stems were $83.63 \pm 6.92 \mathrm{mg} \mathrm{kg}^{-1}, 56.88 \pm 0.84$ $\mathrm{mg} \mathrm{kg}^{-1}$ and $23.05 \pm 1.73 \mathrm{mg} \mathrm{kg}^{-1}$, respectively (Table 3 ). The TF and BF were all above the reference value (1.0) for hyperaccumulation, and with the increase of $\mathrm{Cd}$ concentrations, $\mathrm{Cd}$ uptake from the soil-water to plants decreased but its transport from root to shoots increased (Table 3). In general, $\mathrm{Cd}$ is accumulated more in the belowground parts (roots) than in the aboveground parts (shoots) of plants, such as soybean (Shamsi et al., 2010), some Asteraceae plants (De Maria et al., 2013) and Solanaceae plants (Çikili et al., 2016). However, in present study, the accumulation of $\mathrm{Cd}$ in the aboveground parts was nearly 2 times that found in the belowground part (roots) $(P<0.05$; Table 3$)$. This may contribute to its higher translocation and bioaccumulation factor to $\mathrm{Cd}$ in the mixed medium of soil and water. Song et al. (2014) also found that, at solutions containing $200 \mathrm{mM} \mathrm{Cd}$, the concentration of $\mathrm{Cd}$ in shoots was 3 times more than that of the roots of Brassica Rapa, which may contribute to its higher shoot-to-root metal accumulation ratio capacity. This suggests that $A$. donax has a higher capacity for uptake $\mathrm{Cd}$ and has different mechanisms of tolerance, 
physiological transport, and accumulation of $\mathrm{Cd}$ in a mixed medium of soil and water, such as wetland. One possible reason may be that, under present conditions, $\mathrm{Cd}^{2+}$ was easily absorbed by plants because $\mathrm{Cd}^{2+}$ is of considerable importance to plants and animals due to its high water solubility, mobility, persistence, and toxicity even in minute amounts (di Toppi and Gabbrielli, 1999). Sabeen et al. (2013) also found that Cd uptake in $A$. donax was higher in hydroponics cultures with Hoagland solution (Liu et al., 2008), which showed higher bioaccumulation and translocation factor values, compared with soil-based environments.

Table 3. Concentrations (mean values) of $\mathrm{Cd}$ in $A$. donax plants after 4-month cultivation (mg kg-1)

\begin{tabular}{|c|c|c|c|c|c|c|}
\hline \multirow{2}{*}{ Concentration (mg L ${ }^{-1}$ ) } & \multirow{2}{*}{ Soil $\left(\mathrm{mg} \mathrm{kg}^{-1}\right)$} & \multicolumn{2}{|c|}{ Aboveground $\left(\mathrm{mg} \mathrm{kg}^{-1}\right)$} & \multirow{2}{*}{$\begin{array}{c}\text { Belowground/(Roots, } \\
\left.\mathrm{mg} \mathrm{kg}^{-1}\right)\end{array}$} & \multirow{2}{*}{ TF } & \multirow{2}{*}{ BF } \\
\hline & & Leaves & Stems & & & \\
\hline 0.00 & $0.011^{f}$ & $0.1^{\mathrm{e}}$ & $0.1^{\mathrm{e}}$ & $0.2^{\mathrm{e}}$ & $1.0^{c}$ & $18.2^{a}$ \\
\hline 0.01 & $11.7^{e}$ & $46.0^{d}$ & $6.2^{d}$ & $36.8^{d}$ & $1.4^{b}$ & $3.1^{b}$ \\
\hline 0.025 & $19.2^{\mathrm{d}}$ & $53.2^{\mathrm{cd}}$ & $9.7^{\mathrm{cd}}$ & $42.7^{c}$ & $1.5^{b}$ & $2.3^{c}$ \\
\hline 0.05 & $34.1^{c}$ & $60.8^{b c}$ & $14.0^{\mathrm{bc}}$ & $46.7^{c}$ & $1.6^{a b}$ & $1.4^{\mathrm{e}}$ \\
\hline 0.125 & $45.7^{b}$ & $67.3^{b}$ & $17.9^{\mathrm{b}}$ & $52.2^{b}$ & $1.6^{a b}$ & $1.9^{d}$ \\
\hline 2.50 & $58.7^{a}$ & $83.6^{a}$ & $23.1^{\mathrm{a}}$ & $56.9^{a}$ & $1.8^{\mathrm{a}}$ & $1.8^{d}$ \\
\hline PCC & $0.71 * *$ & $0.57^{*}$ & $0.69 * *$ & $0.45^{*}$ & $0.53^{*}$ & -0.25 \\
\hline
\end{tabular}

Note: TF: translocation factor; BF: bioaccumulation factor; PCC: Pearson correlation coefficient between Cd concentration and each parameter. Data with different superscript letters indicate a significant difference at $P<0.05$ and asterisks indicate significant differences at $* P<0.05$ and ${ }^{* *} p<0.01$

Table 4. Chlorophyll fluorescence parameters and gas exchange parameters of $A$. donax at different $C d$ treatment levels

\begin{tabular}{ccccccccc}
\hline Concentration $\left(\mathbf{m g ~ L}^{-1}\right)$ & SPAD & Yield & $\mathbf{F}_{\mathbf{v}} / \mathbf{F}_{\mathbf{o}}$ & $\mathbf{F}_{\mathbf{v}} / \mathbf{F}_{\mathbf{m}}$ & $\mathbf{P n}$ & $\mathbf{T r}$ & $\mathbf{G s}$ & $\mathbf{C i}$ \\
\hline 0.00 & $34.57^{\mathrm{a}}$ & $0.80^{\mathrm{a}}$ & $4.34^{\mathrm{a}}$ & $0.81^{\mathrm{a}}$ & $8.33^{\mathrm{a}}$ & $0.25^{\mathrm{ab}}$ & $3.90^{\mathrm{a}}$ & $1.73^{\mathrm{a}}$ \\
\hline 0.01 & $35.13^{\mathrm{a}}$ & $0.76^{\mathrm{a}}$ & $3.50^{\mathrm{b}}$ & $0.78^{\mathrm{a}}$ & $6.42^{\mathrm{a}}$ & $0.13^{\mathrm{b}}$ & $2.00^{\mathrm{b}}$ & $1.64^{\mathrm{ab}}$ \\
\hline 0.025 & $36.31^{\mathrm{a}}$ & $0.71^{\mathrm{a}}$ & $2.72^{\mathrm{d}}$ & $0.73^{\mathrm{a}}$ & $7.31^{\mathrm{a}}$ & $0.24^{\mathrm{ab}}$ & $3.05^{\mathrm{ab}}$ & $1.59^{\mathrm{ab}}$ \\
\hline 0.05 & $37.63^{\mathrm{a}}$ & $0.78^{\mathrm{a}}$ & $3.65^{\mathrm{b}}$ & $0.79^{\mathrm{a}}$ & $10.68^{\mathrm{a}}$ & $0.36^{\mathrm{a}}$ & $4.52^{\mathrm{a}}$ & $1.39^{\mathrm{b}}$ \\
\hline 0.125 & $35.24^{\mathrm{a}}$ & $0.68^{\mathrm{b}}$ & $2.06^{\mathrm{c}}$ & $0.67^{\mathrm{b}}$ & $9.72^{\mathrm{a}}$ & $0.32^{\mathrm{a}}$ & $4.54^{\mathrm{a}}$ & $1.53^{\mathrm{ab}}$ \\
\hline 2.50 & $39.20^{\mathrm{a}}$ & $0.79^{\mathrm{a}}$ & $3.84^{\mathrm{b}}$ & $0.79^{\mathrm{a}}$ & $7.08^{\mathrm{a}}$ & $0.22^{\mathrm{ab}}$ & $3.38^{\mathrm{a}}$ & $1.77^{\mathrm{a}}$ \\
\hline
\end{tabular}

Note: Data with different superscript letters indicate a significant difference at $P<0.05$

\subsection{Physiological parameters}

Compared to the control treatment, there were no differences in the relative chlorophyll content (SPAD), or the effective $(Y)$ and the potential $\left(F_{v} / F_{m}\right)$ photochemical efficiency of PSII (except that at $0.125 \mathrm{mg} \mathrm{L}^{-1}$ ) (Table 4). This result suggested that PSII reaction centers were not damaged because SPAD is a measurement of photosynthesis, $F_{v} / F_{m}$ provides the most frequently applied chlorophyll fluorescence ratio and $Y$ is a more realistic impression of the overall leaf photosynthetic condition (Wang et al., 2016). However, $F_{v} / F_{0}$ was inhibited by $\mathrm{Cd}$ application. The possible reason may be that the ratio $F_{v} / F_{0}$ shows higher amplitude at stress conditions because all changes of $F_{v}$ and/or $F_{0}$ are immediately reflected by it. Thus, in leaves with partial photo inhibition the values of $F_{v} / F_{m}$ changed very little, whereas $F_{v} / F_{0}$ already exhibited a large significant decline (Lichtenthaler et al., 1992). The present study showed that there were no differences in $\mathrm{Pn}, \mathrm{Tr}$ (except that at $0.01 \mathrm{mg} \mathrm{L}^{-1}$ ), Gs (except that at $0.01 \mathrm{mg} \mathrm{L}^{-1}$ ), and $\mathrm{Ci}$ (except that at $\left.0.05 \mathrm{mg} \mathrm{L}^{-1}\right)$, indicating that the photosynthetic system was not harmed and showed a strong tolerance of this plant to the increased heavy metal concentrations in the soil-water medium. The results agreed with previous studies, in which Pn, Gs, $\mathrm{Tr}, \mathrm{Ci}$ and stomatal limitation (Ls) of $A$. donax were unaffected by irrigation with trace metal aqueous solution containing high concentrations of $\mathrm{Cd}$ (Prasad, 1995; Papazoglou et al., 2005; Alshaal et al.,
2015). This finding probably contributed to the fact that A. donax possesses a very effective antioxidant system, which protects chloroplast and stomatal functioning (Alshaal et al., 2015).

\subsection{Antioxidant enzymes activities}

Compared to control plants, SOD activity in the leaves of A. donax was significantly increased (from 0.01 to $\left.0.125 \mathrm{mg} \mathrm{L}^{-1}\right)$ or slight increased $\left(2.5 \mathrm{mg} \mathrm{L}^{-1}\right)$ under $\mathrm{Cd}$ stress (Figure 1a), suggesting that the conversion of $\mathrm{O}_{2}^{-}$ increased since SOD catalyzes the dismutation of $\mathrm{O}_{2}^{-}$to $\mathrm{H}_{2} \mathrm{O}_{2}$ and $\mathrm{O}_{2}$ (Han et al., 2010). POD activity was significantly increased but CAT activity was significantly decreased at the mid-level Cd concentration (from 0.025 to $0.125 \mathrm{mg} \mathrm{L}^{-1}$ ) compared with the control group (Figure $1 b, c)$, suggesting that POD plays a critical role in converting $\mathrm{H}_{2} \mathrm{O}_{2}$ into water and molecular $\mathrm{O}_{2}$ in the mid-level $\mathrm{Cd}$ treatment group. Meanwhile, CAT activity was higher in response to the highest $\mathrm{Cd}$ concentration ( $\left.2.5 \mathrm{mg} \mathrm{L}^{-1}\right)$ and the lowest $\left(0.01 \mathrm{mg} \mathrm{L}^{-1}\right) \mathrm{Cd}$ concentrations, suggesting that CAT played an important role in converting $\mathrm{H}_{2} \mathrm{O}_{2}$ into water and molecular $\mathrm{O}_{2}$ in the lowest and highest $\mathrm{Cd}$ concentrations. One of the possible explains could be related to the mixed medium of soil and water since $\mathrm{Cd}$ has high water solubility, mobility, persistence, and toxicity even in minute amounts (di Toppi and Gabbrielli, 1999). In the lowest Cd concentrations, SOD activity increased (Figure 1a), suggesting the 
production of $\mathrm{H}_{2} \mathrm{O}_{2}$. Although there was no significantly difference in POD activity (Figure 1b) between the control and the lowest $\mathrm{Cd}$ concentrations, there was significantly difference in CAT activity (Figure 1c). This result indicated that the deficiency of POD activity could be compensated by the induction of CAT activity. In general, SOD activity was increased with increasing concentration of $\mathrm{Cd}$ at earlier stages of plant growth in soil (Gonçalves et al., 2007; Han et al., 2008; Ahmad et al., 2015), but decreased with the exposure time in A. donax (Han et al., 2008). Thus, after a 4-month cultivation, SOD showed a low values in the highest $C d$ concentration, which weakened the capability of $A$. donax to detoxify ROS. However, SOD activity was still higher in the highest $\mathrm{Cd}$ concentrations than in the control, suggesting the production of $\mathrm{H}_{2} \mathrm{O}_{2}$ still increased. Although POD activity at this treatment was not changed, the increased CAT activity may scavenge the increased $\mathrm{H}_{2} \mathrm{O}_{2}$. Previous study also showed that the CAT activities of $A$. donax increased resistance to the stress of multi-metals in soil, which plays an important role in countering $\mathrm{As}, \mathrm{Cd}, \mathrm{Pb}$-induced oxidative stress (Miao et al., 2012). These results indicated that the decrease in CAT was compensated for by the induction of POD activity and these two enzymes function concurrently to remove $\mathrm{H}_{2} \mathrm{O}_{2}$ in both soil medium and soil-water medium. This phenomenon is similar to the effect of As in Pteris vittata (Cao et al., 2004). This might explain why we were unable to observe toxicity symptoms at the date of the experiment completion in the plants at all concentrations.

(a)

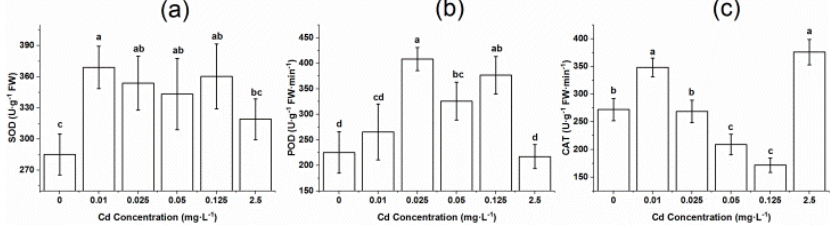

Figure 1. Effects of $\mathrm{Cd}$ stress on (a) superoxide dismutase (SOD), (b) peroxidase (POD) and (c) catalase (CAT) activities in the leaves of $A$. donax. FW: fresh weight. Different lower case letters on the top of the bars denote significant differences $(P<0.05)$ among different $\mathrm{Cd}$ treatments

\section{Conclusion}

In conclusion, although the accumulation of $\mathrm{Cd}$ in the aboveground parts (leaves and stems) was nearly 2 times that in the belowground part (roots) of $A$. donax, all treatment plants showed no detrimental or toxic symptoms or physiological disturbances, suggesting A. donax may have a higher capacity to uptake $\mathrm{Cd}$ in the simulated wetland without destroying its photosynthesis system. The oxidative stress may involve the mechanism of $\mathrm{Cd}$ toxicity with $A$. donax showing a strong tolerance to the increased $\mathrm{Cd}$ pollution. These findings indicate that A. donax possesses a very effective antioxidant system that protects chloroplast and stomatal functioning, and therefore, may have a potential use for phytoremediation in wetland environment.

\section{Acknowledgement}

This study was supported by the Guangxi Scientific and Technological Project (Guikezhong1598014-3), the National Natural Science Foundation of China (31660154, 31860023), the Natural Science Foundation of Guangxi Province (2015GXNSFAA139072, 2015GXNSFEA139001) and the Fund of Guangxi Key Laboratory of Plant Conservation and Restoration Ecology in Karst Terrain (No.16-A-03-02).

\section{References}

Ahmad P., Sarwat M., Bhat N.A., Wani M.R., Kazi A.G. and Tran L.S. (2015), Alleviation of cadmium toxicity in brassica juncea I. (czern. and coss.) by calcium application involves various physiological and biochemical strategies. Plos One, 10, e0114571.

Alshaal T., Domokos-Szabolcsy E., Marton L.J., Katai-Balogh P., Elhawat N., El-Ramady H. and Fari M. (2013), Phytoremediation of bauxite-derived red mud by giant reed, Environmetal Chemistry Letters, 11, 295-302.

Alshaal T., Elhawat N., Domokos-Szabolcsy É., Kátai J., Márton L., Czako M., El- Ramady H. and Fári M. (2015), Giant reed (Arundo donax L.): a green technology for clean environment. In: Ansari A.A., Gill S.S., Gill R., Lanza G.R., Newman L. (eds) Phytoremediation: Management of Environmental Contaminants, Springer Science Business Media B.V., I, 3-20.

Cao X., Ma L.Q. and Tu C. (2004), Antioxidative responses to arsenic in the arsenic-hyperaccumulator Chinese brake fern (Pteris vittata L.), Environmental Pollution, 128, 317-325.

Chen Y., Li T.Q., Han X., Ding Z.L., Yang X.E., and Jin Y.F. (2012), Cadmium accumulation in different pakchoi cultivars and screening for pollution-safe cultivars. Journal of Zhejiang University-Science B, 13, 494-502.

Çikili Y., Samet H. and Dursun S. (2016), Cadmium toxicity and its effects on growth and metal nutrient ion accumulation in Solanaceae plants, Tarım Bilimleri Dergisi, Journal of Agricultural Science, 22, 576-587.

De Maria S., Puschenreiter M. and Rivelli A.R. (2013), Cadmium accumulation and physiological response of sunflower plants to $\mathrm{Cd}$ during the vegetative growing cycle. Plant, Soil and Environment, 59, 254-261.

di Toppi S.L. and Gabbrielli R. (1999), Response to cadmium in higher plants, Environmental and Experimental Botany, 41, 105-130.

Elhawat N., Alshaal T, Domokos-Szabolcsy É., El-Ramady H., Márton L., Czakó M., Kátai J., Balogh P., Sztrik A., Molnár M., Popp J. and Fári M.G. (2014), Phytoaccumulation potentials of two biotechnologically propagated ecotypes of Arundo donax in copper-contaminated synthetic wastewater, Environmental Science and Pollution Research, 2014, 21, 7773-7780.

El-Ramady H.R., Alshaal T., Domokos-Szabolcsy E., Shalaby T., Bayoumi Y., Elhawat N., Sztrik A., Prokisch J. and Fári M. (2014), Selenium and its role in higher plants. In: Lichtfouse $\mathrm{E}$ (ed) Environmental Chemistry for a Sustainable World, vol 6. Springer, Dordrecht

Genty B., Briantais J.M. and Baker N.R. (1989), The relationship between the quantum yield of photosynthetic electron transport and quenching of chlorophyll fluorescence, Biochimica et Biophysica Acta, 990, 87-92. 
Gonçalves J.F., Becker A.G., Cargnelutti D., Tabaldi L.A., Pereira L.B. and Battisti V., et al. (2007), Cadmium toxicity causes oxidative stress and induces response of the antioxidant system in cucumber seedlings. Brazilian Journal of Plant Physiology, 19, 119-23.

Han Z.P., Yang Z.H., Wu X. and Zhang H. (2010), Effects of lead stress on the antioxidant enzymes activities in Arundo donax Linn. Journal of Nuclear Agriculture Sciences, 24, 846-850.

He S.Y., Yang X.E., He Z.L. and Baligar V.C. (2017), Morphological and Physiological Responses of Plants to Cadmium Toxicity: A Review, Pedosphere, 27, 421-438.

Imran H., Shamsi G., Jilani, Zhang G.P. and Kang W. (2008), Cadmium stress tolerance through potassium nutrition in soybean. Asian Journal of Chemistry, 20, 1099-1108.

Johna R., Ahmadb P., Gadgila K. and Sharmab S. (2009), Heavy metal toxicity: Effect on plant growth, biochemical parameters and metal accumulation by Brassica juncea L., International Journal of Plant Production, 3, 65-76.

Kausar S., Mahmood Q., Raja I.A., Khan A., Sultan S., Gilani M.A. and Shujaat S. (2012), Potential of Arundo donax to treat chromium contamination. Ecological Engineering, 42, 256-259.

Leitenmaier B. and Küpper H. (2013), Compartmentation and complexation of metals in hyperaccumulator plants, Frontiers in Plant Science, 4, 374.

Lichtenthaler H.K., Burkart S., Schindler C. and Stober F. (1992), Changes in photosynthetic pigments and in vivo chlorophyll fluorescence parameters under photoinhibitory growth conditions, Photosynthetica, 27, 343-353.

Lichtenthaler H.K., Langsdorf G., Lenk S. and Buschamann C. (2005), Chlorophyll fluorescence imaging of photosynthetic activity with the flash-lamp fluorescence imaging system, Photosynthetica, 43, 355-369.

Liu Y.N., Guo Z.H., Xiao X.Y., Wang S., Jiang Z.C. and Zeng P. (2017), Phytostabilisation potential of giant reed for metals contaminated soil modified with complex organic fertiliser and fly ash: A field experiment. Science of the Total Environment, 576, 292-302.

Liu D., Li T.Q., Jin X.F., Yang X.E., Islam E. and Mahmood Q. (2008), Lead induced changes in the growth and antioxidant metabolism of the lead accumulating and non-accumulating ecotypes of Sedum alfredii. Journal of Integrative Plant Biology, 50, 129-140.

Malik A. (2007), Environmental challenge vis a vis opportunity: the case of water hyacinth. Environment International, 33, 122-138.

Mazur R., Sadowska M., Kowalewska Ł., Abratowska A., Kalaji H.M., Mostowska A., Garstka M., Krasnodębska-Ostręga B. (2016), Overlapping toxic effect of long term thallium exposure on white mustard (Sinapis alba L.) photosynthetic activity. BMC Plant Biology, 16(1), 191.

Metwally A., Safronova V.I., Belimov A.A. and Dietz K.J. (2005), Genotypic variation of the response to cadmium toxicity in Pisum sativum L. Journal of Experimental Botany, 56, 167178.

Miao Y., Xiao X., Miao X., Guo Z. and Wang F. (2012), Effect of amendments on growth and metal uptake of giant reed (Arundo donax L.) grown on soil contaminated by arsenic, cadmium and lead, Transactions of Nonferrous Metals Society of China, 22, 1462-1469.
Mirza N., Mahmood Q., Pervez A., Ahmad R., Farooq R., Shah M.M. and Azim M.R. (2010), Phytoremediation potential of Arundo donax in arsenic contaminated synthetic wastewater, Bioresource Technology, 101, 5815-5819.

Moussa H.R. and Alla M.A.A. (2016), Beneficial Effects of Selenium for Alleviating Cadmium Toxicity in Pisum sativum L., European Journal of Academic Essays, 3, 67-75.

Nassi N., Angelini L.G. and Bonari E. (2010), Influence of fertilization and harvest time on fuel quality of giant reed (Arundo donax L.) in central Italy. European Journal of Agronomy, 32, 219-227.

Nassi od N.N., Roncucci N. and Bonari E. (2013), Seasonal dynamics of aboveground and belowground biomass and nutrient accumulation and remobilization in giant reed (Arundo donax L.): a three-year study on marginal land, Bioenergy Research, 6, 725-736.

Papazoglou E.G., Karantounias G.A., Vemmos S.N. and Bouranis D.L. (2005), Photosynthesis and growth responses of giant reed (Arundo donax L.) to the heavy metals $\mathrm{Cd}$ and $\mathrm{Ni}$, Environment International, 31, 2243-249.

Pinto A.P., Mota A.M., De V.A. and Pinto F.C. (2004), Influence of organic matter on the uptake of cadmium, zinc, copper and iron by sorghum plants, Science of the Total Environment, 326, 239.

Prasad M.N.V. (1995), Cadmium toxicity and tolerance in vascular plants. Environmental \& Experimental Botany, 35, 525-545.

Radosław M., Monika S., Łucja K., Agnieszka A., Kalaji H.M., Agnieszka M., Maciej G. and Beata K.O. (2016), Overlapping toxic effect of long term thallium exposure on white mustard (sinapis albal.) photosynthetic activity. BMC Plant Biology, 16, 191.

Sabeen M., Mahmood Q., Irshad M., Fareed I., Khan A., Ullah F., Hussain J., Hayat Y. and Tabassum S. (2013), Cadmium phytoremediation by Arundo donax L. from contaminated soil and water, BioMed Research International, 2013, 324830 .

Sappin-Didier V., Vansuyts G., Mench M. and Briat J.F. (2005), Cadmium availability at different soil ph to transgenic tobacco overexpressing ferritin. Plant and Soil, 270, 189-197.

Sasmaz M., Akgul B., Yıldırım D. and Sasmaz A. (2016), Bioaccumulation of thallium by the wild plants grown in soils of mining area. International Journal of Phytoremediation, 18, 1164-1170.

Shabana K., Qaisar M., Iftikhar A.R., Afsar K., Sikandar S., Mazhar A.G. and Shahida S. (2012), Potential of Arundo donax to treat chromium contamination, Ecological Engineering, 42, 256-259.

Shah K. and Nahakpam S. (2012), Heat exposure alters the expression of SOD, POD, APX and CAT isozymes and mitigates low cadmium toxicity in seedlings of sensitive and tolerant rice cultivars, Plant Physiology and Biochemistry, 57, 106-113.

Shahbaz M., Ashraf M., Akram N.A., Hanif A., Hameed S., Joham S. and Rehman R. (2011), Salt-induced modulation in growth, photosynthetic capacity, proline content and ion accumulation in sunflower (Helianthus annuus L.), Acta Physiologiae Plantarum, 33, 1113-1122.

Shahid M., Dumat C., Khalid S., Niazi N.K. and Antunes P.M.C. (2017), Cadmium Bioavailability, Uptake, Toxicity and 
Detoxification in Soil-Plant System, Reviews of Environmental Contamination and Toxicology, 24, 173-137.

Shamsi I.H, Jiang L., Wei K., Jilani G., Hua S. and Zhang G.P. (2010), Alleviation of cadmium toxicity in soybean by potassium supplementation. Journal of Plant Nutrition, 33, 1926-1938.

Song Y., Hudek L., Freestone D., Puhui J., Michalczyk A.A., Senlin Z. and Ackland M.L. (2014), Comparative analyses of cadmium and zinc uptake correlated with changes in natural resistance-associated macrophage protein (NRAMP) expression in Solanum nigrum L. and Brassica Rapa, Environmental Chemistry, 11, 653-660.

Wang Y., Chai L.Y., Yang Z.H., Mubarak H. and Tang C.J. (2016), Chlorophyll fluorescence in leaves of Ficus tikoua under arsenic stress, Bulletin of Environmental Contamination and Toxicology, 97, 576-581.

Williams C.M.J., Biswas T.K., Black T., Heading S. (2008), Pathways to prosperity: second generation biomass crops for biofuels using saline lands and wastewater, Agricultural Sciences, 21, 28-34.

Zema D.A., Bombino G., Andiloro S., Zimbone S.M. (2012), Irrigation of energy crops with urban wastewater: effects on biomass yields, soils and heating values, Agricultural Water Management, 115, 55-65.

Zhi Y.Y., Li P., Shi J.C., Zeng L.Z. and Wu L.S. (2016), Source identification and apportionment of soil cadmium in cropland of Eastern China: a combined approach of models and geographic information system, Journal of Soils and Sediments, 16, 467-475. 